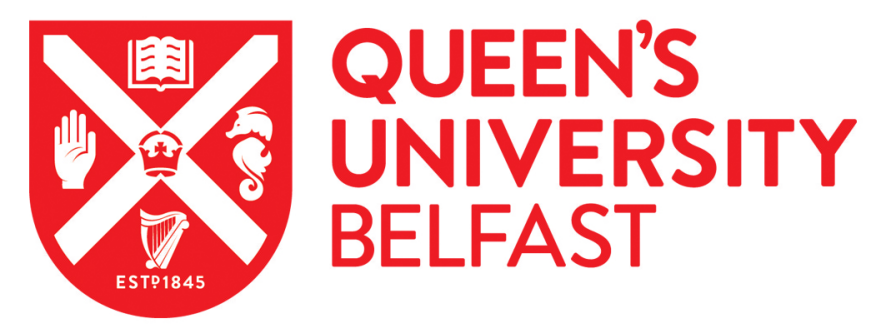

\title{
Secular trends in stroke mortality and early-life environment
}

Kee, F. (2003). Secular trends in stroke mortality and early-life environment. The Lancet, 361(9362), 1059-1060.

\section{Published in:}

The Lancet

\section{Queen's University Belfast - Research Portal:}

Link to publication record in Queen's University Belfast Research Portal

\section{General rights}

Copyright for the publications made accessible via the Queen's University Belfast Research Portal is retained by the author(s) and / or other copyright owners and it is a condition of accessing these publications that users recognise and abide by the legal requirements associated with these rights.

Take down policy

The Research Portal is Queen's institutional repository that provides access to Queen's research output. Every effort has been made to ensure that content in the Research Portal does not infringe any person's rights, or applicable UK laws. If you discover content in the Research Portal that you believe breaches copyright or violates any law, please contact openaccess@qub.ac.uk. 


\section{Patent law}

Sir-In response to Amir Attaran's criticisms of our report (Feb 15, p 613), ${ }^{1}$ we think that Attaran raises important issues, but our interpretation of most of them is different.

Attaran's first point is that patents apply to individual products not to a class, so they do not automatically create a monopoly. In theory yes, but in practice no. Implementation of the patent system in a situation characterised by market failure has contributed to poor access to many drugs, even in developed countries. True price competition is absent between patented products of the same class, which effectively puts whole classes of new drugs out of reach of many countries that do not provide drug coverage.

The point we were trying to make with esomeprazole is that (effectively) it is omeprazole. It is the S-isomer. This case is a classic example of evergreening. In our view, esomeprazole's development as a socalled new product is an exercise in marketing, not science, which is only possible with the current patent system and in the presence of market failure. Development of this drug means that large amounts of money were spent with no prospect of great medical progress. Patents are being used to exploit the rather naive belief of doctors, consumers, and the media in the value of new drugs.

Attaran's third point is the muchdebated issue of in-country patents. Here, two issues are at work. The absence of patents in small developing countries is unimportant if those countries cannot import a low-cost generic version because of patent protection in countries that have the capacity to manufacture generics. In the African situation that Attaran discusses, patenting an antiretroviral in large markets such as South Africa may effectively remove incentive for generic manufacturers to produce and export to small African markets that do not have patent protection. The second issue is that when drugs are given the level of patent protection they enjoy in lucrative markets, they are priced so that a very high rate of return is guaranteed to manufacturers, and this conditions future expectations of return on investment. Even large developing countries may remain unattractive markets compared with North America, Europe, or Japan. More competition in developed markets and tighter margins-eg, by reduction of patent protection-could force large international manufacturers to cut their high costs and look at expansion of their markets in middle-income and lowincome countries.

We agree partly with Attaran's penultimate point: government interventions modify the patentee's theoretical ability to set prices. However, price controls are not solely used: the buying power of governmentsubsidised programmes - coupled with sensible use of reference-based price negotiations (or tendering) - provide some countries with prices that are much lower than in the free market of the USA.

Our response to Attaran's last point is that no one perspective can cover all dimensions of these complex issues. Patents are not the sole problem: the way they have been granted and used has led to the mess we are in.

* David Henry, Joel Lexchin

* School of Medical Practice and Population Health, University of Newcastle, NSW 2298 Australia (DH); and Department of Family and Community Medicine, University of Toronto, Canada (JL)

(e-mail: mddah@mail.newcastle.edu.au)

Attaran A. Physicians and patent law. Lancet 2003; 361: 613-14.

\section{latrogenic Cushing's syndrome: a different story}

Sir-The Correspondence letter by Reto Krapf (Dec 7, p 1884) ${ }^{1}$ highlights irrational drug use patterns in developed countries. The scenario regarding irrational use of drugs in India, and perhaps in many other developing countries, is different.

We report a case of Cushing's syndrome in a 3-month-old infant due to irrational use of a steroid by a complementary and alternative medicine practioner. The infant was admitted to our hospital in September, 2001, with rapid breathing and chest indrawing. On physical examination she had cushingoid facies, truncal obesity, drumstick limbs, and paper-thin skin with striae. On enquiry, the mother showed us a small bottle of betamethasone, which was prescribed to the child at 15 days of life for upper respiratory tract infection. She had continued receiving this drug for the next 2 and a half months. We gave her ceftriaxone intravenously, and the steroid was gradually tapered off and stopped. The infant recovered and was discharged after 4 weeks in hospital. When last seen in August, 2002, there were no complaints.

Guidelines for over-the-counter steroids in developing countries are lacking. ${ }^{2}$ Kshirsagar and colleagues estimate that more than $30 \%$ of prescriptions by medical practitioners are irrational. ${ }^{3}$ Complementary and alternative medicine practitioners, who are untrained medically, prescribe allopathic medicines openly, and even prohibited drugs are available without prescription. ${ }^{4}$ The problem is further compounded by the symbiosis that exists between qualified professionals and complementary and alternative medicine practitioners. Such practitioners refer difficult and serious patients to qualified allopathic private practitioners, and get tipped for the service.

Governments in developing countries must make more serious efforts to enforce the existing laws to improve health care, which presently looks elusive.

Satish Agadi

Department of Paediatrics, Karnataka Institute of Medical Sciences, Vidyanagar, Hubli 580022 India

(e-mail: agadisatish@hotmail.com)

1 Krapf R. Development of Cushing's syndrome after use of a herbal remedy. Lancet 2002; 360: 1884

2 Hui JYH, Woo PCY, Lo SS, Chan JCS. Over the counter medication and its effects. Lancet 2002; 359: 1120 .

3 Kshirsagar MJ, Langade D, Patil S, Patki PS. Prescribing patterns among medical practitioners in Pune, India. Bull World Health Organ 1998; 76: 271-75.

4 George R, Abraham R. Private health in India. Lancet 2002; 359: 1528 .

\section{Secular trends in stroke mortality and early-life environment}

Sir-Debbie Lawlor and colleagues report that the decline of stroke in the 20 th century was mainly attributable to the decline in mortality from haemorrhagic stroke (Dec 7, p 1818). This finding adds to evidence that the causes of haemorrhagic stroke are substantially different to the aetiological factors for ischaemic stroke and coronary heart disease.

We agree with Lawlor that early-life factors could account for this decline in deaths due to haemorrhagic stroke. However, they seem not to have considered the possibility that early-life blood pressure is one such factor. Perhaps this omission is wise, since publication of an extensive metaanalysis of usual blood pressure and vascular mortality, showing that agespecific associations with blood pressure are similar for strokes due to cerebral ischaemia and cerebral haemorrhage, ${ }^{2}$ seems to rule out an explanatory role for blood pressure. However, the findings in this meta-analysis - as in most reports of blood pressure-stroke associationsrelied on blood pressure measured 
during mid-to-late life. The possibility that early-life blood pressure could explain the different trends in mortality by stroke subtype should be considered.

Blood pressure in young adulthood is strongly positively associated with stroke, ${ }^{3}$ and furthermore, it has declined in young individuals since at least the $1950 \mathrm{~s},{ }^{4}$ and possibly before that. ${ }^{5}$ Earlylife environmental changes-perhaps dietary-are a potential cause of this favourable blood-pressure trend. In the future, testing the hypothesis that earlylife blood pressure is a stronger risk factor for haemorrhagic than ischaemic stroke will add further to knowledge of stroke cause, and if correct, could have important implications for preventive efforts.

* Peter McCarron, Mark O McCarron, Liam Murray, Frank Kee

Department of Epidemiology and Public Health, Mulhouse Building, Grosvenor Road, Belfast, BT12 6BJ, UK (PM, LM, FK); Department of Neurology, Royal Victoria Hospital, Belfast (MOM); and *23 Rue Sala, Lyon 69002, France (PM)

(e-mail: peter.mccarron@qub.ac.uk)

1 Lawlor DA, Davey Smith G, Leon DA, Sterne JAC, Ebrahim S. Secular trends in mortality by stroke subtype in the 20th century: a retrospective analysis. Lancet 2002; 360: 1818-23.

2 Prospective Studies Collaboration. Agespecific relevance of usual blood pressure to vascular mortality: a meta-analysis of individual data for one million adults in 61 prospective studies. Lancet 2002; 360: 1903-13.

3 McCarron P, Davey Smith G, Okasha M, McEwen J. Blood pressure in young adulthood and mortality from cardiovascular disease. Lancet 2000; 355: 1430-31.

4 McCarron P, Davey Smith G, Okasha M. Secular changes in blood pressure in childhood, adolescence and young adulthood: systematic review of trends from 1948 to 1998. 7 Hum Hypertens 2002; 16: 677-89.

5 Goff DC, Howard G, Russell GB, Labarthe DR. Birth cohort evidence of population influences on blood pressure in the United States, 1887-1994. Ann Epidemiol 2001; 11: 271-79.

\section{Accuracy of electronically transmitted pathology laboratory reports}

Sir-In the UK, pathology laboratory reports are commonly transmitted to general practices electronically. This process has several advantages, in particular speedier transmission of results. However, concerns have been expressed about errors that can arise if software is not tested thoroughly. ${ }^{1}$

Results and words obtained from the laboratory computers are transmitted to the general practice, where they are matched with Read codes before being displayed on general practitioners' computer screens. The quality of the data displayed depends on the accurate matching of the laboratory data to Read codes selected by general practitioners. We became aware of serious errors in virology reports received by a Cambridgeshire general practitioner, and did a study to investigate the prevalence of these errors.

We extracted 1 month's virology and biochemistry laboratory reports from the pathology laboratory computer for 20 general practices chosen at random. We then visited these practices and cross-checked the data (name, date of birth, laboratory results) with those contained in the general practitioner's computer system.

There was a high rate of inaccurate virology results (mean 9\%, range $0-54 \%)$, most of which were due to inaccurate matching of laboratory results with local Read codes. Examples of errors were anti-HBc laboratory results being matched with an HCV antibody Read code, and "influenza A antibody" being matched to "infant feeding advice". For biochemistry results, there was a smaller error rate $(1 \%, 0-3 \%)$.

In all practices, there was a small error rate for spelling of names $(4 \%$, $0-8 \%)$ and date of birth $(1 \%, 0-4 \%)$. $46 \%$ of these errors were the result of inaccurate data entry in the pathology laboratories, and $54 \%$ were due to incorrect completion of laboratory request forms by general practitioners or practice staff, or to illegible writing.

Practices that used four-bite codes found it more difficult to find suitable matches than those who had five-bite codes available. In practices that used four-bite codes, we were often unable to find suitable matching codes.

The errors in matching name and date of birth were not a serious problem, since by having one of these, the other could almost always be derived. However, errors such as assigning a patient who is positive for anti-HBc (indicating past resolved hepatitis $\mathrm{B}$ infection) to being positive for hepatitis C antibody has serious medical and sociological consequences.

This study has shown that when reports are transmitted electronically, robust audit procedures must be used to test the accuracy of the process. It also emphasises the value of involving pathologists in scrutinising the Read codes available for matching results.

\section{*Tim Wreghitt, Andrew Trull}

\section{* Clinical Microbiology and Public Health} Laboratory (TW), and Department of Clinical Biochemistry (AT), Addenbrooke's Hospital, Cambridge CB2 2QW, UK

(e-mail: tim.wreghit@addenbrookes.nhs.uk)
1 Powsner SK, Wyatt JC, Wright P. Opportunities for and challenges of computerisation. Lancet 1998; 352: 1617-22.

\section{Maintaining linguistic standards}

Sir-Last year you published a Research letter by U Veronesi and colleagues ${ }^{1}$ in which patients who had undergone hysterectomy were described as "hysterectomised women". This description was used again in subsequent Correspondence by J Benson (Nov 30, p 1784). ${ }^{2}$ The word "hysterectomised" does not exist in the English language; moreover, the word "women" is superfluous since men cannot have a hysterectomy. The title should be "tamoxifen for breast cancer after a hysterectomy". As a prestigious English language medical journal you surely have a duty to maintain your linguistic standards.

John R C Logie

The Darroch, Little Cantray, Culloden Moor, Inverness IV2 5EY, UK

e-mail: john.r.c.logie@lineone.net)

1 Veronesi U, Maisonneuve P, Sacchini V, et al. Tamoxifen for breast cancer among hysterectomised women. Lancet 2002; 359: 1122-24.

2 Benson J R. Tamoxifen for breast cancer among hysterectomised women. Lancet 2002; 360: 1784-85.

\section{DEPARTMENT OF ERROR}

Bae $M$, Watanabe $C$, Inaoka $T$, et al. Arsenic in cooked rice in Bangladesh. Lancet 2002; 360: 1839-40-In this Research letter (Dec 7), the third sentence in the fourth paragraph should read "The weight ratio of added water to raw rice ranged between $4 \cdot 5 / 1$ and $5 \cdot 4 / 1$, which is much higher than the typical ratio of $1 \cdot 3 / 1$ used in Japan".

Spranger J, Kroke A, Möhlig M, et al. Adiponectin and protection against type 2 diabetes mellitus. Lancet 2003; 361: 226-28-In this Research letter (Jan 18), the address for A Kroke, M M Bergmann, and $\mathrm{H}$ Boeing should be "Department of Epidemiology, German Institute of Human Nutrition PotsdamRehbrücke".

Prospective Studies Collaboration. Age-specific relevance of usual blood pressure to vascular mortality: a meta-analysis of individual data for one million adults in 61 prospective studies. Lancet 2002; 360: 1903-13-In table B2 in appendix 2 of this Article (Dec 14), the text in the parentheses in the title should be "(as provided for SBP in table 1 of main report)". Furthermore, the second footnote in this table should read, "†Ratio of the cited difference (vi-ii) in usual DBP at the start of each decade to that in baseline DBP." The correct version can be viewed at http://image.thelancet.com/ extras/01 art8300webappendixB_doe.pdf 